\section{Audit committee effectiveness: informal processes and behavioural effects}

\author{
Stuart Turley and Mahbub Zaman \\ Manchester Business School, University of Manchester, Manchester, UK
}

\section{Audit committee effectiveness}

\begin{abstract}
Purpose - This paper seeks to investigate the conditions and processes affecting the operation and potential effectiveness of audit committees (ACs), with particular focus on the interaction between the $\mathrm{AC}$, individuals from financial reporting and internal audit functions and the external auditors.

Design/methodology/approach - A case study approach is employed, based on direct engagement with participants in $\mathrm{AC}$ activities, including the $\mathrm{AC}$ chair, external auditors, internal auditors, and senior management.

Findings - The authors find that informal networks between AC participants condition the impact of the $\mathrm{AC}$ and that the most significant effects of the $\mathrm{AC}$ on governance outcomes occur outside the formal structures and processes. An $\mathrm{AC}$ has pervasive behavioural effects within the organization and may be used as a threat, an ally and an arbiter in bringing solutions to issues and conflicts. ACs are used in organizational politics, communication processes and power plays and also affect interpretations of events and cultural values.

Research limitations/implications - Further research on AC and governance processes is needed to develop better understanding of effectiveness. Longitudinal studies, focusing on the organizational and institutional context of $\mathrm{AC}$ operations, can examine how historical events in an organization and significant changes in the regulatory environment affect current structures and processes.

Originality/value - The case analysis highlights a number of significant factors which are not fully recognised either in theorizing the governance role of ACs or in the development of policy and regulations concerning ACs but which impinge on their governance contribution. They include the importance of informal processes around the $\mathrm{AC}$; its influence on power relations between organizational participants; the relevance of the historical development of governance in an organization; and the possibility that the AC's impact on governance may be greatest in non-routine situations.
\end{abstract}

Keywords Audit committees, Governance, Regulation, Relationship management

Paper type Research paper

\section{Introduction}

Following high-profile corporate governance failures there have been proposals and actions in a number of countries concerning the responsibilities and powers of audit committees (ACs), their mandatory or voluntary status, membership and independence[1]. This trend of development can be seen as part of a wider agenda regarding the potential "globalisation" of corporate governance. Following similar

Earlier versions of this paper were presented at the University of Amsterdam Auditing and Assurance Research Colloquium, the EAA Annual Congress, AFAANZ Conference, APIRA Conference and at staff research seminars at the University of Essex, University of Ghent, Griffiths Business School, Copenhagen Business School and Aarhus School of Business. The authors are grateful to the participants for their comments and suggestions. The constructive comments from two anonymous reviewers of $A A A J$ are gratefully acknowledged.

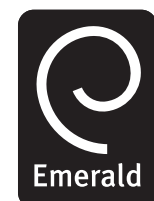

\footnotetext{
Accounting, Auditing \& Accountability Journal Vol. 20 No. 5,2007 pp. $765-788$ (C) Emerald Group Publishing Limited 0951-3574 DOI $10.1108 / 09513570710779036$
} 
AAAJ

20,5

766 projects in areas of financial reporting, harmonisation of governance structures internationally is an important area of current development. Indications of this are apparent from evidence of a significant rise and harmonization in the use of ACs internationally (Collier and Zaman, 2005) and from the European Commission's 8th Directive requiring all public-interest entities in the European Union to have an $\mathrm{AC}$ (EC, 2006).

Notwithstanding the fact that ACs are now a common feature of corporate governance internationally, their effectiveness has been a subject of some concern to both researchers and regulators (Spira, 2002; Turley and Zaman, 2003, 2004). A typical example of this concern is the following reaction to the USA case of Enron, where the $\mathrm{AC}$ has been criticised for failing to identify or prevent certain practices within the company:

One of the mysteries of Enron Corp.'s fall from grace is how an audit committee chock full of talent could have been blind to the company's financial sleight of hand The audit committee followed all the rules - but it let the shareholders down (Business Week, 2002, p. 28).

Existing research has offered limited insight on the operational conditions surrounding $\mathrm{AC}$ activities within organizations. Focusing on the interaction of the $\mathrm{AC}$ with board members and individuals from financial reporting and internal audit functions as well the external auditors, this paper contributes to understanding of the conditions and processes affecting the operation and potential effectiveness of ACs through a case study of the activities of an AC in a major UK company. In contrast with most existing studies, which have investigated ACs using externally available information, this approach involves more direct engagement with internal participants in $\mathrm{AC}$ activities and provides complementary qualitative evidence on the impact of $\mathrm{AC}$ processes. In this context, and given the variety of governance traditions that exists internationally, research that assists understanding of the ways in which mechanisms such as ACs operate within organizations is important. This paper provides evidence regarding the manner in which the workings of an AC can affect organizational outcomes and seeks to extend current research on ACs in a number of ways.

First, while most existing research has examined the existence and characteristics of $\mathrm{ACs}$, this paper investigates $\mathrm{AC}$ processes and their consequences for aspects of governance such as internal control, financial reporting and external audit. The focus of this paper is thus on the manner of AC operation and how this impacts on governance outcomes. Second, the analysis shows the significance of informal processes and power relationships in conditioning AC outcomes and argues that these factors need to be included in theorizing about ACs, alongside more conventionally recognised factors such as membership characteristics. A finding of the paper is that the most significant $\mathrm{AC}$ consequences result from informal processes involving (voluntary) networks of $\mathrm{AC}$ participants and power relations. These dimensions have been largely unexplored in $\mathrm{AC}$ research and do not appear to have been considered in the development of public policy. Third, the paper makes a contribution on research approach by illustrating the insights that can be derived from a case study approach which investigates the AC from inside the organization - the context in which it operates in practice. Overall, the paper demonstrates that the effects associated with the operation of the $\mathrm{AC}$ are significantly affected by the organizational context. The manner in which the $\mathrm{AC}$ affects governance within the organization are related to 
a number of aspects of the context - in particular the events that occur in the life of the organization and the dynamics of the relationships between different constituencies of organizational members impinge on the way the AC conducts itself.

The remainder of the paper is structured as follows. The next section presents a brief commentary on research associated with the development of ACs. This is followed by sections setting out the framework and approach used to analyse the case study, an outline of the case company and an analysis of the evidence obtained regarding the AC's operation and effects. Finally, ideas about theorizing AC processes and concluding observations based upon the research are made in the last section.
Audit committee effectiveness

767

\section{Audit committee research}

Within the context of this paper, it is not appropriate to review the entire growing body of research that has developed relating to corporate governance structures in general or ACs in particular (DeZoort et al., 2002 and Turley and Zaman, 2004 for a review of the AC literature). This section provides only a summary overview of prior studies to establish a number of important points about the character and findings of existing research as a basis for considering the contribution of using a case study approach to enhance understanding of the governance contribution of ACs in operation.

First, in prior research there has been limited investigation of the organizational context and processes associated with AC operations, which may be significant factors affecting the impact and effectiveness of the $\mathrm{AC}$ in actual corporations and thus important in developing our understanding of the role of the AC. In the existing literature, there is a trend in the focus of $\mathrm{AC}$ research moving over time from investigation of AC existence, primarily through studies of voluntary adoption (Pincus et al., 1989; Bradbury, 1990; Collier, 1993; Menon and Williams, 1994), to examination of $\mathrm{AC}$ characteristics, such as the expertise and background of members (Beasley et al., 2000; Carcello and Neal, 2003; Klein, 2002; Yang and Krishnan, 2005). Alongside this trend, research has developed from a focus on the circumstances associated with the presence or absence of an AC (largely through studies of voluntary adoption) to investigation of possible associations between ACs and other variables of interest, for example attributes reflecting the quality of financial reporting (Abbott et al., 2004; Bedard et al., 2004; Krishnan, 2005).

Second, research on ACs has predominantly been conceptualised using agency theory and related economic rationalisations. The resulting empirical evidence is however somewhat mixed. An explanation for the limited results so far may be that the complexities of organizational settings, the power relations around and within corporate entities and the nature of businesses as social systems are not properly represented in simple agency models. An approach focused on studying the AC within organizations may be more likely to address these issues.

Third, to date only a limited amount of research has been conducted on the processes and perceptions surrounding AC activity set in particular organizational contexts (Spira, 2002; Gendron et al., 2004; Sarens and De Beelde, 2006). In seeking to investigate generalised economic models, most researchers have sought to construct and test cross-sectional data sets to reflect the variables of interest. To a certain extent these studies have inevitably relied on relatively crude proxies, for example, the number and duration of meetings as indicators of how "active" an AC is (Abbott et al., 2004, Bedard et al., 2004, Krishnan, 2005). Without denying the contribution of studies using 
AAAJ

20,5

768

these methods, there is also a role for an approach that attempts to look more at the operation of the $\mathrm{AC}$ within its organizational context.

Overall, the focus of extant research has been concerned primarily with the aggregate and the average - that is, what generalised models can be established associated with the form of ACs. In contrast, the focus of public perceptions with respect to governance issues is often on the micro, individual case - that is, why particular (problematic) outcomes have occurred in specific companies. Studies of association indicate some aspects of the conditions for certain governance outcomes, but do not reveal the processes and manner of operation which result in $\mathrm{AC}$ effectiveness or failure. The contribution of a case study approach, as adopted in this paper, is as a complementary means of investigating AC processes within their organizational context to reveal more of what is unobservable in externally available data. Its value derives from the fundamental point that it is important to look at the content of AC operations to develop a proper and better understanding of AC impact, how governance can be designed in a manner to meet desired expectations and the extent to which effective processes can be codified. Additionally, this approach also has the potential to make a contribution towards theorizing about the operation and effects of ACs within organizations.

\section{A framework for researching audit committees}

The main dimension of interest in this study is the processes within an organization whereby the AC exercises influence over governance outcomes. A case study approach allows investigation beyond the formal constitution and official policies to include consideration of behavioural effects and informal processes that condition an AC's governance contribution. It reflects the kind of concerns that are represented in policies on $\mathrm{AC}$ attributes and roles by offering a closer analysis of the AC's operations within its organizational context.

The data for construction and analysis of the case study was gathered from three sources: semi-structured interviews with relevant personnel affected by the AC's activities; internal documents made available by the company; and publicly available information including annual reports. Interviews were conducted on a number of visits, and in some cases individuals were interviewed on more than one occasion. The range of people includes main board members, relevant functional areas of financial reporting, internal audit and risk management, and individuals at different operational levels within those areas. All interviews were tape-recorded and transcribed for analysis. A schedule of the interviewees is set out in Table I.

Table I.

Interviews with relevant personnel
1. Audit committee chair
2. Group finance director
3. Head of finance
4. Head of group internal audit
5. Operations audit manager
6. Operations audit assistant, treasury
7. Operations audit assistant, computing
8. Head of risk and compliance
9. External audit partner 
The information discussed in the main analysis in this paper concerns evidence of the operation of the $\mathrm{AC}$ in the case company, both in general processes related to the $\mathrm{AC}$ and in specific incidents where it appeared to be influential in arriving at particular organizational outcomes. While it is not always possible to say whether or not the same governance outcomes would have resulted without $\mathrm{AC}$ involvement, the focus of interest is the manner in which the $\mathrm{AC}$ was involved in governance issues and how this affected the way in which other actors participated in processes. Adopting this focus, the analysis of the case study is structured around three inter-related, not mutually exclusive, dimensions affecting the context of $\mathrm{AC}$ operation and its impact within organizations - formal processes, informal processes and power relationships:

(1) Formal processes. ACs in many environments are expected to comply with recommendations and/or requirements concerning membership, composition, charters and meetings (SEC, 2003; Smith Committee, 2003). These constitutional components have provided the main basis for data collection, on factors such as such as size, membership structure and meeting frequency, in much of the prior empirical research. In analysing the case it is appropriate to consider the formal processes associated with the $\mathrm{AC}$ which are centred on the regular meetings and specified formal responsibilities.

(2) Informal processes. Business organizations are social systems populated by individuals with norms, values and expectations. Individual behaviour and interaction between individuals result in the establishment of processes outside those recognised in the formal structures. Such processes may be informal in nature, rely on particular attributes amongst key participants, and be exercised on a regular or occasional basis. They may effectively create informal institutional practices in the organization (Burns, 2000; Scott, 2001). These processes and practices constitute part of the "real organization" they help to define organizational rationality and they are likely to be of significance in the way in which organizational issues are managed and resolved (Dirsmith and Covaleski, 1985; Scott, 2001; Shapira, 2000). Informal processes are rarely directly observable externally and, to the extent that they are present in $\mathrm{AC}$ activities, failure to recognise them may limit our understanding of how governance is achieved.

(3) Power relationships. In the political process in organizations, the manner in which matters are resolved involves the exercise of power. Power conditions processes and outcomes (Pfeffer, 1992; Pettigrew, 1992; Burns, 2000). While several alternative frameworks of power have been advanced, they share a common underlying conceptual concern about the relevance of power to interactions within organizations and hence to outcomes (Clegg, 1989; Hardy, 1996; Scott, 2001). The activities of governance structures such as ACs are likely to have an impact on, and be affected by, the exercise of power by a variety of participants drawing their power from a variety of sources. Power holders shape and decide what are issues and what are non-issues and a potential governance issue will become one in the organization only if power holders also define it as such (Hall, 1999). The personal attributes of AC members are important considerations in power relationships.

\section{Audit committee effectiveness}

769 
AAAJ 20,5

770

It is the combination of the above dimensions that provides the main focus of this paper. The formal terms of reference of the $\mathrm{AC}$ is an important document for helping $\mathrm{AC}$ members focus on the discharge of their duties and for helping the board of directors assess the AC's roles and responsibilities. However, the institutional power of the $\mathrm{AC}$ supports the important nature of written terms of reference and its perceived authority to affect organizational outcomes. That authority may be created by and operationalized through activity outside the formal AC meeting context, and may be influenced by the individual power (potentially) exercised by the $\mathrm{AC}$ chair. The respect, values and leadership qualities attributed to the $\mathrm{AC}$ chair and other members, as well as the perceived preparation, vigilance, independence, and level of activity of the AC chair and other members in carrying out their duties are important factors potentially affecting power. Members possessing relevant financial expertise and personalities capable of influencing others are likely to make a difference to governance outcomes. An AC with committed members is likely to have a high level of involvement in and concern for its activity. Similarly, the level of AC member oversight can range from one of extreme conscientiousness to merely "rubber stamping" the actions and reports of others. The interests of different functional areas within an organization, the relationship between top management and other levels of the organization, and the relationship between management and the external auditors could all be influenced by the effect of the $\mathrm{AC}$ on power relationships.

The framework thus recognises the dynamic nature of the factors affecting the context of AC operations. Formal processes, informal processes and power relationships are related to the organizational context. These dimensions are not static but rather are subject to change over time. The history of relationships between organizational participants, the impact of past events as well as the organization's (regulatory) environment can all affect both formal and informal processes as well as power relationships. This paper provides evidence of examples from one organization illustrating such aspects of context and how they condition governance outcomes.

Owing to limitations of access and empirical data the scope of the paper does not extend to providing a historical explanation for the observations with a focus on the chronology of events and changes as would be achievable in a longitudinal study covering the passage of time. Also, the intention in this paper is not to argue the case for the relevance of a particular theory by reference to the case, but rather to use the above classification (formal processes, informal processes and power relationships) as a skeletal framework for structuring the analysis of the evidence. On the basis of the empirical insights from the case study a number of ideas are developed further in the final section of the paper with a view to providing some additional contribution towards theorizing $\mathrm{AC}$ operation and effects[2].

\section{The case study company}

The company

At the time the study was undertaken, the case company, hereafter referred to as Ashburton plc, was a FTSE-100 financial services company[3]. It had a market capitalisation in excess of £5bn in 2000[4]. The company's primary operations are in the UK, but in recent years it has also expanded into other parts of Europe and Asia. Originally a building society[5], it converted to a bank in the early 1990s and numerous internal changes followed as the company responded to its new environment. A large 
proportion of the company's business is in savings products and mortgage lending but following deregulation of financial services in the UK during the 1980s, it expanded into other areas of commercial banking, with some associated acquisitions of other institutions. In common with most building societies, Ashburton's nineteenth century origins were linked to a specific geographical locality, but it has grown to become a nation-wide institution, with a branch network throughout the UK and a presence in most urban/commercial centres.

The Board of Directors of Ashburton has 13 members, including eight non-executive directors. Within the company's organizational structure the following functional areas are most relevant to the work of the $\mathrm{AC}$ :

- Group finance. Headed by the Group Finance Director, with responsibility for financial reporting, preparation of the annual financial statements, etc. Financial reporting is overseen by the head of finance, reporting to the Group Finance Director.

- Internal audit. The senior position here is the Head of Group Internal Audit, who has a direct reporting line to the Chief Executive and is assisted by an Operations Audit Manager and a team of internal auditors.

- Risk and compliance. This is a relatively new separate function, with a Head of Risk and Compliance, responsible to the Chief Executive and also responsible for preparing certain reports considered by the AC.

\section{The audit committee}

The AC at Ashburton existed for some time prior to the study, linked to long-standing institutional practice in the sector[6]. The AC's terms of reference have been amended from time to time to reflect changes in the external environment, with a clear distinction being drawn between the board's responsibility for the company's governance and control systems and the AC's role in reviewing these matters:

The Board has responsibility for ensuring that the requisite systems of control of the Company's business and its records are established in accordance with the provisions of the Companies Act 1985/Banking Act 1987 (as amended from time to time), regulations made thereunder and in accordance with best accounting practice, and the Audit Committee shall be responsible to the Board for reviewing those systems of control over the Company's business (Emphasis in original terms of reference).

Specific areas of responsibility, relating to internal control, financial reporting and external audit are discussed later in the case analysis, but the $\mathrm{AC}$ terms of reference also recognise general powers "to investigate any activity within the Audit Committee's terms of reference, including seeking information from any employee" and "to obtain external legal or other independent professional advice and to secure the attendance of outsiders with relevant experience and expertise if appropriate".

In compliance with then relevant UK codes (Cadbury Committee, 1992; Hampel Committee, 1998), the AC is made up of three non-executive directors, none of whom had any prior association with the company. The AC's membership is also consistent with the US recommendations about the financial literacy of AC members (Blue Ribbon Committee, 1999; SEC, 2003). The AC chair is a non-executive with a prominent position in public life, who has held significant offices in (quasi) governmental bodies. A qualified lawyer, he was first appointed as a non-executive director in the 1990s and
Audit committee effectiveness 
AAAJ

20,5

772 has significant experience in industry, but did not hold a full-time position or a non-executive directorship in another company. The second AC member, a qualified accountant, has also been a director for several years and chair of a listed company. The third member became a non-executive director while chair of a major investment bank, a position he retired from in the mid 1990s, and at the time of the study did not hold an executive or non-executive position in another company.

\section{Analysis of audit committee processes}

As outlined earlier, a case study approach can provide insights on the effectiveness of AC operations in two ways. First, it offers the opportunity to go beyond formal attributes and other measured external signals to allow consideration of the processes by which the AC operates. Second, evidence from within an organization can reveal particular instances where the $\mathrm{AC}$ is perceived as having an impact that may not be immediately observable from external disclosures. The analysis in this section addresses both these aspects and follows the structure referred to earlier of:

- formal processes;

- informal processes; and

- nature and exercise of power relationships around the AC.

The final section of the paper reintegrates these findings and discusses ideas towards theorizing the operation and effects of ACs.

\section{Formal processes}

In the Company's annual report, disclosure with respect to the $\mathrm{AC}$ is as follows:

The Board has established a number of standing committees. The Audit Committee monitors the adequacy of the Group's internal controls, accounting policies and financial reporting. It also maintains a liaison with the internal and external auditors. The Committee meets four times each financial year, which includes part of one meeting being held between the committee members and the external auditors in private.

Table II provides an indication of the content of the four scheduled meetings annually.

The meetings are highly structured around a standing agenda, shown in Table III.

\begin{tabular}{|c|c|c|}
\hline Meeting & Specific focus & Regular items \\
\hline May & $\begin{array}{l}\text { Review the policies and procedures on which the } \\
\text { audit committee would be relying during the year }\end{array}$ & $\begin{array}{l}\text { Progress reports on outstanding } \\
\text { control issues and on internal } \\
\text { audit activity }\end{array}$ \\
\hline August & Review the interim financial statements & \\
\hline December & $\begin{array}{l}\text { Review the results of the external auditor's } \\
\text { interim work and the internal audit plan for } \\
\text { the forthcoming year }\end{array}$ & Bank of England s39 report \\
\hline February & $\begin{array}{l}\text { Review the final accounts and financial } \\
\text { statements together with reviews of the various } \\
\text { high level control processes and the work of } \\
\text { internal and external audit }\end{array}$ & Ad hoc reports requested by the $\mathrm{AC}$ \\
\hline
\end{tabular}

Table II.

$\mathrm{AC}$ cycle of meetings 


\begin{tabular}{|c|c|c|}
\hline Meeting & Agenda items $^{\mathrm{a}}$ & effectiv \\
\hline \multirow[t]{10}{*}{ May } & Matters from previous meeting & \\
\hline & Actions arising from previous meeting & \\
\hline & Review of progress on major control issues & \\
\hline & Review of internal audit activity and progress against plan & \\
\hline & $\begin{array}{l}\text { Review of external anditors' final management report for the previous year } \\
\text { Review of external audit strategy and related fees }\end{array}$ & 773 \\
\hline & Review of accounting policies and any proposed changes for the year & \\
\hline & Review of the process of risk management for the year & \\
\hline & Review of fraud detection and prevention policies & \\
\hline & Review of group compliance policy and approach & \\
\hline & Any other business & \\
\hline \multirow[t]{6}{*}{ August } & Matters from previous meeting & \\
\hline & Actions arising from previous meeting & \\
\hline & Review of progress on the resolution of major control issues & \\
\hline & Review of interim results and financial statements & \\
\hline & Review of internal audit activity and progress against plan & \\
\hline & Any other business & \\
\hline \multirow[t]{7}{*}{ December } & Matters from previous meeting & \\
\hline & Actions arising from previous meeting & \\
\hline & Review of progress on major control issues & \\
\hline & $\begin{array}{l}\text { Review of the management report from the external auditors interim work and } \\
\text { any issues requiring consideration for the final accounts }\end{array}$ & \\
\hline & Review of internal audit activity and progress against plan & \\
\hline & Review of internal audit plan for the forthcoming year & \\
\hline & Any other business & \\
\hline \multirow[t]{8}{*}{ February } & Matters from previous meeting & \\
\hline & Actions arising from previous meeting & \\
\hline & Review of progress on major control issues & \\
\hline & Review of final results and financial statements & \\
\hline & Review of main points arising from external auditors final account work & \\
\hline & $\begin{array}{l}\text { Review of the report on the operation of the policies on risk management, fraud } \\
\text { prevention and detection and group compliance }\end{array}$ & \\
\hline & Review of summary report on internal audit activity for the previous year & \\
\hline & Any other business & Table III. \\
\hline \multicolumn{2}{|c|}{ 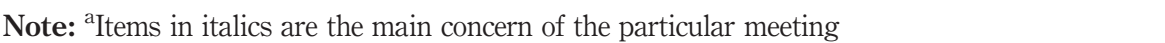 } & $\mathrm{AC}$ agendas for meetings \\
\hline
\end{tabular}

Much of each meeting involves reviewing various reports relating to internal control, financial reporting and external audit.

The formal operations of the $\mathrm{AC}$ via its regular meetings have not had much substantive change over time, except that formalised reporting of the compliance function has moved from the board to the AC and membership of the committee has changed following non-executive retirements. The AC terms of reference state that:

The Group Finance Director, Head of Group Internal Audit and a representative of the external auditors should normally attend meetings. Other members of the Board also have the right to attend. However, at least once a year, the Audit Committee shall meet with the external auditors without executive directors being present.

The participation of the Head of Group Internal Audit at this level may have been significant in enhancing perceptions of the standing of internal audit activity. In terms 
AAAJ

20,5

\section{4}

of executive level, the Head of Group Internal Audit is somewhat equivalent to the position of Head of Finance with respect to financial reporting, but that functional area is also represented by a more senior, main board executive director. This position on representation was seen by some internal audit staff as a signal of the importance of their function. According to the AC chair, internal control and audit have over time become prominent features of $\mathrm{AC}$ activity:

The control issue seems to be, over the period that I've been on the Committee, taking more time.

However, when judged by the formal processes alone, the interviews and documentary evidence suggest that the direct impact of the $\mathrm{AC}$ on matters of internal control and audit is limited. The AC receives a large number of internal audit reports, graded high, medium or low priority. The internal audit classification acts to structure the attention given to an issue and so the activity of the $\mathrm{AC}$ and its potential influence is highly dependent on the agency of internal audit (Sarens and De Beelde, 2006). The Head of Group Internal Audit describes this gatekeeping role:

Ultimately [my aim is] to give [the Audit Committee] comfort that risks are being managed and if they're not to provide them with a measure of why and how those risks are not managed. Consequently, [the Audit Committee] needs to have specific things drawn to its attention, if they are sufficiently serious.

In addition, action on internal audit and compliance reports is primarily dependent on executive processes. The information that is reported to the $\mathrm{AC}$ is in most cases also required for executive management purposes. For example, a quarterly schedule of control issues reported to the $\mathrm{AC}$ is produced for the Group Management Committee which meets monthly. The $\mathrm{AC}$ does not appear to create a significant demand for additional information:

There is a bit of polishing obviously, because you tend to end up with more colour pictures and more sort of rehearsed scripts once you get to an Audit Committee than perhaps you had in internal meetings. But it is essentially part of the day-to-day executive information (Group Finance Director).

The action of getting remedial action, the process of obtaining management's acknowledgement of the seriousness of the issues, all work within the executive processes as opposed to the non-executive process (Operations Audit Manager).

There is only limited evidence of the AC questioning or challenging internal audit findings, for example by asking for additional reporting or further detail for a subsequent meeting. The influence of the $\mathrm{AC}$ on the agenda and work plan of internal audit also appears to be limited. The primary active concern of the $\mathrm{AC}$ with respect to internal control appears to be to ensure that the internal audit plan is met. This limited role in specific internal control matters may be explained by the AC's lack of detailed knowledge:

I don't believe [the Audit Committee] has the experience or the grasp of detail to say "that's right or wrong". So at the moment I think there is an element of rubber-stamping [of the internal audit plan] (Head of Group Internal Audit).

A similar picture is evident with respect to the impact of the AC on external audit activity. "It is the Board rather than the Audit Committee that chooses [the auditors]" (AC Chair). 
The AC does not have authority on matters such as auditors' appointment and fees[7]. There is little evidence of the $\mathrm{AC}$ having any direct influence on the design of the audit, or of the external auditors doing anything differently from what they would have done in the absence of the $\mathrm{AC}$. The external auditors present the audit plan to the $\mathrm{AC}$ after it has been discussed with executive management but, perhaps unsurprisingly, the discussions at the $\mathrm{AC}$ do not normally lead to any adjustments to the plan. Questions from the $\mathrm{AC}$ tend to focus on business issues, rather than procedural aspects of the audit plan. It has, for example, challenged the external auditors' preliminary observations on certain business matters. At the conclusion of the audit, the external auditors present their findings to the $\mathrm{AC}$ and report the key issues found during the audit. Again the AC generally tends not to probe the auditors particularly on the findings, but does expect to be fully briefed:

[Audit findings is] a standing agenda item towards the end of the year. Some audit committees are quite happy for you to just talk to the issues. [But in this company] they like chapter and verse on all material issues, and that in written form so they can take it away and think about it and come well-prepared (External Audit Partner).

Overall, the formal processes associated with internal audit and control, financial reporting and external audit operate with a minimum of involvement from the AC. While the $\mathrm{AC}$ acts as a monitor, there is little evidence that it plays any significant proactive role in these processes. Formally the AC is very much a "receiving and responding" body and it is therefore very dependent on the manner in which other parties choose to interact with, and provide information to, the AC. The formal processes of the $\mathrm{AC}$ in Ashburton suggest two observations. First, the participation of executive management in $\mathrm{AC}$ meetings could influence the degree of freedom the $\mathrm{AC}$ has in exercising its monitoring role through its formal meetings. Second, the nature of the scheduled agenda, with the emphasis on receiving reports which have already been subject to executive consideration or action, could mean that $\mathrm{AC}$ meetings provide the "form" of governance, but that the substance of AC effects lie elsewhere. Both these points suggest that informal processes are more likely to provide substantive evidence of AC effectiveness.

\section{Informal processes}

Analysis of the case study evidence demonstrates that informal processes of communication and interaction are critical to understanding the roles played by the AC. As noted earlier this aspect has largely been unexplored in existing AC research. Beyond the formal business of the regular meetings, interaction between the AC, executive management and the external auditors influences corporate governance outcomes, and some of the strongest evidence of AC impact on organizational life comes from outside the formal meetings. The critical nature of informal communications and interactions affecting power relations around the $\mathrm{AC}$ and hence corporate governance outcomes is illustrated by evidence from three episodes where the authority of the $\mathrm{AC}$ was influential in resolving organizational issues. These episodes illustrate how the specifics of organizational context, including its history, influence the $\mathrm{AC}$ process and the way in which $\mathrm{AC}$ impinges on organizational activity.

Episode one relates to a contest over the allocation of resources to various functional units within the company. The Head of Group Internal Audit, who had been appointed recently, was presented on his arrival with a requirement for budget cuts and the

\section{Audit committee effectiveness}

775 
AAAJ

20,5

\section{6}

proposed loss of staff in internal audit was quite significant. An informal channel of communication was utilised by the Head of Group Internal Audit to raise concerns with the $\mathrm{AC}$ chair and to mobilise his participation in the process to bring about a different outcome:

... I've been here a month and I've been asked to give up so much of my resources. What is the Audit Committee's view? Are they going to support me when I say that I would like to at least look at what's going on before I reduce staff? The AC Chair said, "Of course, you don't have to ask the question" (Head of Group Internal Audit).

While the regular contest over the annual budget may not seem to be a major governance issue, the fact that the support of the AC chair was activated to influence the actual allocation is significant. The resources allocated to internal audit were different from what they otherwise would have been; that is, in terms of control and audit, there was a different corporate governance outcome. A company participant in the budget process, the Head of Group Internal Audit called upon the AC chair as an ally and source of authority to influence that outcome.

Episode two concerns the discovery by internal audit of reporting errors in accounting documents prepared by Group Finance. The AC chair explained how consideration of this issue was initiated:

[Group Finance] staff seemed to have put to capital rather than income various matters concerned with IT expenditure. The Head of Group Internal Audit rang me up, and the two of us met to discuss the matter.

Further information is provided by the Head of Group Internal Audit:

We had an exercise here, where the reporting of some expenditure had been misallocated between capital and revenue. And it's been done on a systematic basis to improve short-term results. It's quite serious, though it's not a huge amount. It's serious in the context of this year's profit and whatever. I went to see [the AC Chair] about that and I told him two things. One is that we're doing this and it's going to be bad news for the group. And secondly, it means that I've had to divert resources onto it, which means that our Audit Plan is going to be missed by x percent. And rather than surprise you with that at the Audit Committee, I thought I ought to tell you.

It should be noted that there was no formal requirement for internal audit to report this matter to the $\mathrm{AC}$, but the existence of the channel of informal communication facilitated the action. In addition it was apparent that internal audit saw the presence of the $\mathrm{AC}$ as giving greater significance to its activities within the company. As a consequence, the Head of Group Internal Audit was motivated to demonstrate to the AC chair the value of their work and their credibility as an organizational unit and thus to build alliances around the $\mathrm{AC}$ to influence potential contests or conflicts between internal audit and other functional areas. The evidence here is consistent with the findings of other studies that a supportive organizational culture and a trusting relationship encourage the reporting of wrongdoing (Miceli and Near, 1984; Hooks et al., 1994).

The internal audit function pursued a policy of "no surprises" and thus when a matter was considered to be significant it was promptly brought to the attention of the AC Chair:

I would go to [the AC Chair] if I thought that in some way internal audit was being hampered, or stopped from doing its job. And in fact l've thought about [doing that] ... because I had a 
situation where I wasn't very happy with the way in which we were dealing with something. I thought internal audit was being blocked and to some extent ... if you looked at it from the outside, you'd say we could be seen to be being manipulated, and I wasn't happy with that. And if I had not resolved it with my boss, the chief executive, my next step would have been to go and see [the AC Chair].

The evidence here suggests that internal auditors would normally report any concerns first to the chief executive (their usual line management), however, if the issue relates to the chief executive or other senior management at an equivalent or higher level in the organizational hierarchy to internal audit the matter is likely to be reported to the AC.

Episode three involves a situation a few years previously when Internal Audit discovered that a senior executive had been misusing the resources of the company. This finding was reported immediately to the AC Chair, who brought it to the attention of the board chair. It was decided that the executive, who at the time of the discovery was on holiday overseas, must be met on arrival at Heathrow airport, and prevented from returning to the company offices. The $\mathrm{AC}$ chair described the impact of this incident:

The facts and the allegations at that stage came out, through Internal Audit doing checks on where the money had gone and what the expenditure had been and so forth.

[Through Internal Audit] the Audit Committee was able to discover that quite a lot of bad things had been going on for quite a long time, but nobody had dared say anything about it because they thought they would be frozen out or something of that sort.

As a consequence, the company introduced a Code of Ethics and provided a whistle blowing policy allowing employees to report suspicious matters. The communication channel for such matters is Internal Audit, then the AC chair and through him the Board Chair. This policy goes beyond requirements of UK governance codes (Cadbury Committee, 1992; Hampel Committee, 1998) applicable at the time to the company. However, it is consistent with development in the USA (SEC, 2003) and in the UK, where the Smith Report (2003) recommends that the AC should review arrangements by which staff of the company may, in confidence, raise concerns about possible improprieties in matters of financial reporting or other matters. It should be noted that Hooks et al. (1994) found codes of conduct alone have little impact if top management does not reinforce them by actions such as establishing reporting channels and encouraging their use. The Ashburton case shows the importance of AC encouragement and support for the reporting of wrongdoings.

Ad hoc meetings held between the AC chair and the external auditors, usually at the latter's initiative, also help to encourage a climate that is conducive for raising concerns informally with the AC. Both auditors and AC chair are comfortable with informal communication and "bouncing off" matters of interest:

[The External Audit Partner] has arranged private meetings, just the two of us, him and me, at his offices or over lunch or whatever to see if there are any particular problems (AC Chair).

On business issues we will talk frankly. Many of the business issues translate to control issues. Some of the issues are connected with the style of the Chief Executive, for example. And we tell them, but at one to one meetings (External Audit Partner).

\section{Audit committee effectiveness}

777 
AAAJ

20,5

778

We brief [the AC Chair] on certain key discussions which we might have had with the executives that we feel the non-executives might want to focus on at their full Board meetings (External Audit Partner).

The evidence in this section suggests that although various participants in the different functions relevant to $\mathrm{AC}$ responsibilities have formal channels of communication with the $\mathrm{AC}$, corporate governance outcomes also appear to be significantly affected by informal communication and interactions. Participants appear to welcome the ability to communicate in this manner. It offers some discretion over disclosure of information, the opportunity to speak "off the record" and the possibility of political action to achieve desired outcomes. Relying on such informal mechanisms could also run certain dangers for governance, but clearly these processes have been more important than the formal processes in the Ashburton AC's role in resolving problematic issues. In terms of promoting good corporate governance it is perhaps in these non-routine situations where there is the greatest need for $\mathrm{AC}$ action.

The findings relating to informal processes and communications is significant given that existing research on ACs has tended to restrict itself to formal structures and communications (Beasley et al., 2000; Bedard et al., 2004; Carcello and Neal, 2003; McMullen, 1996). Similarly, the role of the AC with respect to the reporting of corporate wrongdoing has not been addressed in $\mathrm{AC}$ research. This case shows that the contribution of ACs to governance processes and outcomes is influenced by the existence and use of informal channels of communication. Governance codes issued in many countries tend to emphasize formal communication. Likewise, existing research on ACs has not focused on the role of informal processes; the evidence in this case demonstrates that this is an important aspect of corporate governance.

The Ashburton case suggests that wrongdoings are likely to be reported to the AC when the $\mathrm{AC}$ is perceived to have high standing in the organization and there is a climate encouraging informal interaction between functional units, especially internal audit, and the AC. After forming an assessment of a personal obligation to report, internal auditors are likely to consider which (if any) of the reporting alternatives to embrace. They may choose to report the matter through line management to the chief executive or to the more independent audit committee. Internal auditors can be expected to assess the effectiveness of each alternative from an instrumental perspective (i.e. will the alternative work?) and from a cost/benefit perspective (i.e. balancing perceived benefits against expected risks). The evidence presented above suggests that simply requiring ACs to review arrangements (Smith Committee, 2003) by which staff of the company may, in confidence, raise concerns about possible improprieties in matters of financial reporting is likely to have limited impact on governance. The episodes also show that whereas in the past the internal audit function might have been reluctant to report such matters "fearing being shut out" this does not seem to be so at present. The discovery of errors and wrongdoings (see earlier instances in the episodes) referred to earlier and the manner in which they were resolved affected the present context of the $\mathrm{AC}$ operation and the nature of its interaction with organizational members and resulted in a new policy on the reporting of wrongdoings.

\section{Power relationships}

As noted earlier, to a large extent the Ashburton AC operates in a responsive manner it is very dependent on matters being drawn to its attention and is not a major initiator 
of enquiries. Nonetheless, the AC does influence power relationships between organizational participants and thus can have indirect as well as direct governance effects. Areas where the influence of the $\mathrm{AC}$ on the balance of power between participants is apparent include the relationship between external auditors and executive management, the position of particular functions relative to each other, and the manner in which functions are able to pursue their own responsibilities.

The ability of the AC to influence the power relationship between external auditors and executive management is a function of the standing, quality and experience of its members. The Ashburton case suggests that power of the AC is a critical factor influencing governance outcomes. The AC has something of an aura which influences the way in which participants regard its activities and also the manner in which they perceive their own position relative to other organizational participants. The existence of the formal structure enables the AC to exercise its institutional power and also provides a mechanism for communication between external auditors (and internal auditors) and non-executive directors and thus a control in case, in the words of the Group Finance Director "We as executive management are too overbearing in our dealings with these people". He continued:

How much clout the Audit Committee has within the organization, how effective it is, depends on the experience of the non-executive directors ... The present Audit Committee team, they are all individually sort of strong characters, with a clear view of what's going on. No one would dream of pulling a fast one on any of them.

Although the AC may not have detailed knowledge, for example, about what is "right" or "wrong" coverage with respect to the internal audit plan (see quote from Head of Group Internal Audit on p. 10 above which relates to a specific choice), the Group Finance Director's observation above suggests that the AC at Ashburton does affect the behaviour and attitudes of relevant organizational participants, i.e. neither the Head of Internal Audit nor the Group Finance Director consider that they will be able to "pull a fast one" on the AC. The AC thus affects the "tone" of governance in the organization.

The strengthening of independence that comes from the $\mathrm{AC}$ is likely to be mitigated by the extent to which in practice the appointment and remuneration of the auditors are controlled or influenced by executive management rather than the $\mathrm{AC}$ alone. It appears that for the main day-to-day and routine activity the external auditors will rely on negotiation and communication with management, but the role of the AC becomes more critical in dealing with the non-routine. Politically the external auditors can use informal contact with the $\mathrm{AC}$ to establish the conditions in which the support of the $\mathrm{AC}$ could be activated if necessary.

An example of the external auditors using the $\mathrm{AC}$ to strengthen their position vis-à-vis executive management is provided by the case of provisions required to cover potential compensation for selling customers inappropriate pension products. The external auditors perceived management to be taking a rather lenient view, "got terribly worked up about it" and made a full presentation at an AC meeting. The power of the $\mathrm{AC}$ in Ashburton, mobilized as an ally of, in this case, the external auditor, was instrumental in bringing about a different governance outcome. The $\mathrm{AC}$ reacted against the company proposal and this enabled the non-executives to take the issue to the full board. As described by the External Audit Partner:

\section{Audit committee effectiveness}

779 
AAAJ

20,5

780
Because of the noises we made, and the discomfort of a couple of the non-execs, they went into a full Board meeting soon after that and the whole thing was changed. I mean, that's because a couple of the non-execs themselves felt strongly that they could not be associated with an announcement going out in that fashion. They had the clout, if you like, the respect within the Board, to have their views understood and acted upon.

The pension misselling and provisions issue illustrates two points. First, it shows the potential of the $\mathrm{AC}$ within Ashburton to have a real impact on financial reporting numbers and one aspect of how an AC can exercise authority in this aspect of governance. Second, the outcome that resulted was the product of interaction between more than one governance mechanism. It is doubtful that the accounts would have been adjusted without the combination of forceful representation from the external auditors and the ability of the AC members to carry influence with the full Board, this demonstrates the importance of both collective and personal power in bringing out desirable governance outcomes:

We have seen non-executives [at Ashburton] actually roll up their sleeves and engage with [executive management]. It's because they're not dependent upon this organization for their livelihood, if you like. And it comes down to that. These guys hold high profile jobs elsewhere $\ldots$ and they are very mindful of their own reputation (External audit partner).

In routine situations the $\mathrm{AC}$ has limited impact on power relationships. Normally, agreement is reached between those in Group Finance and the external auditors and the agreed position is taken to the $\mathrm{AC}$ in the expectation that it will be approved. When unusually a disagreement occurs, as in the above example relating to provisions, "a great deal of lobbying takes place before the Audit Committee meeting" (Group Finance Director), with the $\mathrm{AC}$ being perceived as having considerable personal and institutional power. The $\mathrm{AC}$ is seen as "the judge and jury" in these deliberations:

It is the Audit Committee who will be deemed to be the objective arbiter of who is right, and it's quite a powerful force in that respect (Group Finance Director).

The AC also has an impact on power relationships within the company, influencing both the relative power of particular functions and the way in which those functions operate. The dynamics of change in relationships cannot be divorced from the prevailing organizational context and past events and illustrates the interconnectedness of social phenomena. The Group Finance function, responsible for the preparation of financial statements, appears to have a somewhat arms length relationship with the AC, viewing it as a potential constraint on the discretion that might otherwise be exercised. The internal audit team, in contrast views the $\mathrm{AC}$ as enhancing the status and importance of its activities.

For example, in instances where a functional or business unit questions the work of internal audit, reference could be made to the AC "requiring" the work. This kind of comment is perceived as having "quite an impact ... it scares them" (Operations Audit Manager). Internal audit thus uses the AC, when necessary, as a form of threat if they fail to obtain something from a line manager. The Group Finance Director also shares this perception of the AC's power and impact on the influence of others:

The Audit Committee is ... referred to with a bit of awe and reverence and certainly within the [financial] reporting, control and compliance activities that particularly report to it. It's seen as being pretty important ... and undoubtedly, members of the Audit Committee are 
assumed to have powers far in excess of that of ordinary mortals ... They are perhaps seen as being very senior people and you wouldn't dream of doing anything other than putting on your best possible presentation for that group of people.

The influence of the $\mathrm{AC}$ is seen as pervading the company and increasing the power of the internal audit function. The Operations Audit Manager commented how the AC sets a "tone" that enables internal audit to have a certain degree of influence in the organization. However, references to the backing of the $\mathrm{AC}$ tend to be used primarily for situations in which internal audit staff are dealing with units lower down the organizational structure. Interestingly, in situations where there is a difference of opinion with another function at the same or a higher level, a matter is taken up with the $\mathrm{AC}$ only after very careful consideration. The $\mathrm{AC}$ may be used as a threat only in circumstances where the legitimacy of that claim is not likely to be challenged. Thus, internal audit recognises the limitations, and possible risks, involved in taking matters up with the $\mathrm{AC}$ and is conscious that this can undermine the co-operation and open access it requires from other functions. The $\mathrm{AC}$ influences the political strategies and tactics employed by various agencies within the company. Internal audit staff appear willing to use the $\mathrm{AC}$ as an obtrusive means to exercise power, but are very aware of the risks associated with such a political strategy. The Operations Audit Manager explains:

I have used it [the threat to take something to the $\mathrm{AC}$ ] but it really has to be in very serious circumstances because you can't use it to bluff. If you're going to use it you've got to deliver it.

Having threatened to take a particular issue to the AC the gamble is that the Audit Committee is going to react in the way that you want them to react. And on the basis that the people that you may be threatening have also got an avenue through executive directors who may be in attendance at the $\mathrm{AC}$, it could easily backfire.

This section has provided evidence of the $\mathrm{AC}$ being instrumental in influencing the nature of power relationships around relevant aspects of organizational activity. The instances analyzed above illustrate how the AC may be used as a threat, as an ally, and as an arbiter in conflict situations and to enhance general perceptions about certain processes. It conditions the way in which some organizational participants see themselves - and others. The key to this influence on organizational power appears to be linked to the perceived standing of the members of the $\mathrm{AC}$, and the personal power of the $\mathrm{AC}$ chair. It is doubtful that concerns about corporate wrongdoings (reporting of misappropriation by the chief executive; misreporting of income by the finance function) and about the level of resources given to internal audit would have been brought to the AC had it not been perceived as possessing significant "clout" within the organization. Clearly, in the Ashburton case internal audit considered that reporting their concerns to the AC would lead to improved governance. Internal audit's assessment of the seriousness of the issues and its confidence in the AC's power seemed to have alleviated any fear of retaliation from senior management for whistle-blowing to the AC. Additionally, the culture of encouraging such reporting, without any fear of retaliation, by the organization needs to be matched with a similar attitude in the AC. Thus, whereas most existing studies have focused on the powers of the $\mathrm{AC}$ as reflected in formal rights and responsibilities (for example, in governance codes and AC terms of reference), this paper demonstrates the importance of considering how personal attributes and collective behaviour realize effective power in

\section{Audit committee effectiveness}

781 
AAAJ

20,5

782 the organization. Both institutional powers and personal behaviour by AC members enabled desirable governance outcomes in Ashburton. Power relationships, as shown by the evidence here, are not static. Rather the dynamic nature of the relationships and the use informal processes to affect governance outcomes are influenced by the organizational context including past events in the life of the organization. In contrast to most existing $\mathrm{AC}$ studies, which fail to give adequate consideration to the organizational context of AC operations (Abbott et al., 2004; Bedard et al., 2004; Carcello and Neal, 2003; Krishnan, 2005), the analysis of the case evidence demonstrates the interconnectedness of social phenomena and in particular the combined effect of formal structures and codes, informal processes and power relationships in conditioning governance outcomes.

\section{Discussion and concluding comments}

This paper has reported a case study of the processes involved in the activities of the $\mathrm{AC}$ in a major UK public company at a particular point in time. It provides evidence of $\mathrm{AC}$ impact on governance outcomes, of potential tensions that could act against the contribution of the $\mathrm{AC}$, and of the behavioural impact of the $\mathrm{AC}$ on other organizational participants. The case study was able to identify a number of instances in which the participation of the $\mathrm{AC}$ was significant in influencing governance outcomes. These situations, and the manner in which they were resolved would not have been readily observable from the normal publicly available information sources and indicate the value of a case study approach as a means of bringing internal perceptions and information into view. A contribution of the case analysis is that it highlights that a number of significant factors, which are not fully recognised either in theorizing the governance contribution of ACs or in the development of policy and regulations affecting ACs, impinging on the governance contribution of ACs. Four such factors are referred to as follows:

(1) the importance of informal processes around the AC;

(2) its influence on power relations between organizational participants;

(3) the relevance of the historical development of governance in an organization; and

(4) the possibility that the AC's impact on governance may be greatest in non-routine situations.

First, reliance on standardized structure and formal features (as is evident in recent reforms)[8] such as terms of reference are unlikely to deliver a uniform governance contribution. The effects of the $\mathrm{AC}$ do not result solely from the existence of formal structures and processes (as tend to be specified in governance codes) but are additionally dependent on informal voluntary interaction with (senior) management and (internal and external) auditors. The significance of the informal processes and communications found in this paper does not suggest that all formal requirements for ACs (Smith Committee, 2003; Ramsay Report, 2001; EC, 2006) should be dispensed with. However, at a time when many are arguing that the general concerns over AC effectiveness should be answered by greater codification of $\mathrm{AC}$ characteristics and operations, it is significant that in almost all of the instances reported where the $\mathrm{AC}$ could be considered to have "made a difference" in Ashburton, its impact was achieved 
through informal processes involving voluntary networks. This does not necessarily however support a suggestion that formal processes are irrelevant. The point is to contrast this finding with an approach which believes that a standardized governance role and impact can be achieved through the adoption of standard code provisions on constitutional matters and responsibilities. The findings regarding the importance of informal processes and communications are particularly important because existing research (Beasley et al., 2000; Carcello and Neal, 2003; Klein, 2002) has mainly relied on formal characteristics as signals and variables for testing AC effectiveness. The evidence from this case suggests that many of the factors which contribute to effective governance cannot easily be codified in governance codes. Externally verifiable AC characteristics (such as membership and meetings) provide only a partial guide to AC activity and effectiveness.

Second, the analysis of the case study evidence in this paper shows that ACs have significant influence on power relations between relevant organizational participants. The existence and operation of the $\mathrm{AC}$ has pervasive behavioural effects, for example in influencing the way in which those engaged in internal audit perceive the status and importance of their own and others' functional activities. The episodes referred to earlier illustrate the importance of organizational context and how the $\mathrm{AC}$ can serve varied roles, effectively being called upon to act as an ally in certain circumstances, as an arbiter in others and being used at times as a source of threat to support the authority of other organizational participants. Identifying the three roles of the AC (a threat, an arbiter, or an ally) found in the Ashburton case is a novel addition to the AC literature which has tended to focus more on constitutional responsibilities. Further research investigating the factors and circumstances in which the $\mathrm{AC}$ is more likely to play one, as opposed to another, of these roles should provide significant insights for the theorizing of $\mathrm{AC}$ processes and governance outcomes.

The standing of the individuals that comprise the committee, particularly that of the $\mathrm{AC}$ chair, appears to be a key element in the impact of the $\mathrm{AC}$ on the organization. The success of both formal and informal processes, the degree to which participants will judge involvement with the $\mathrm{AC}$ to have potential value to affect outcomes, and the influence of the $\mathrm{AC}$ on the exercise of power relations all depend to a large extent on whether the AC membership is credible for the responsibilities it has and whether it can be considered a significant agency in the organization. Formally the AC is very much a "receiving and responding" body and it is therefore very dependent on the manner in which other parties choose to interact with, and provide information to, the AC. The perceived personal attributes of the AC combined with a general organizational culture encouraging informal interactions between functional units and the $\mathrm{AC}$ seem to have significant influence on governance outcomes.

The constitutional powers derived from the provisions of governance codes and the AC's terms of reference (Smith Committee, 2003; SEC, 2003) on their own are likely to have limited impact on effectiveness. It is the combination of constitutional position with both the individual power of AC members and the AC's impact on power relations between other organizational participants that produces the most significant AC outcomes. Even within a uniform constitutional code, the influence ACs exercise in different organizations is likely to vary with the AC's personal power which cannot be standardised by governance codes.

\section{Audit committee effectiveness}

783 
AAAJ 20,5

784
Third, the case study evidence in this paper shows that in understanding the role and influence of the $\mathrm{AC}$, it is important to recognize organizational context and the historical development of the organization. Most published studies tend to conceptualize ACs with little or no attention to this aspect of their organizational context. In Ashburton, it is possible that the impropriety of the senior executive and the changing of the head of internal audit had a significant impact on the company's attitude towards accountability and internal control. Events in a company's life - such as the discovery of wrongdoing and impropriety and changes in key senior management - will exert significant influence on subsequent governance processes and outcomes, hence governance should be viewed as a dynamic and evolving attribute of an organization. Analysis of evidence in earlier sections of this paper shows that at the company level a major control failure can result in heightened awareness and focus on the $\mathrm{AC}$ and its function as well as greater codification of AC activities. The impact of organizational changes and events, and specifically those relating to the reporting of wrongdoings, on the dynamics of the role of the $\mathrm{AC}$, and whether in the absence of such stimulus there is a danger that the AC's contribution will be largely passive and static, are potentially important issues for future research.

Owing to the limitations of data and in particular access to individuals who may have been party to these events we are unable to explore the issues in greater depth. Longitudinal studies however could help to provide complimentary evidence on how historical events in an organization and significant changes in the regulatory environment (for instance major corporate failure and introduction of new law and/or regulation) affect current structures and processes. We recognize that the environment of corporate governance has been changing over recent years, particularly following Enron and other scandals, and that, as the operation of ACs continues to develop and change, different aspects of behaviour may have emerged. This point does not, however, weaken our conclusions and in particular the significance of informal processes and power relationships in conditioning governance outcomes. Rather it provides further support for more attention to the organizational and institutional context of $\mathrm{AC}$ operations.

Fourth, related to the issue of historical context, the Ashburton case suggests that the greatest impact of ACs is in non-routine situations, when the AC is instrumental in mediating organizational solutions outside existing experience or precedent, or the pre-existing organizational order. While it is true that what is non-routine is defined by what is incorporated in routine responsibilities and context, our point here is that reliance on standard situations does not automatically recognize the inevitability of the informal. An implication of this finding is that it may therefore be difficult to obtain a full picture of $\mathrm{AC}$ effectiveness through generalised external measures, based on routine activity, that do not adequately reflect the prevailing organizational context of AC operations. For example, compared with Abbott et al. (2004) who find that ACs composed of independent directors and which meet at least twice per year are less likely to be associated with fraudulent or misleading reporting, the analysis in this paper shows the important role of informal processes involving voluntary networks and power relationships in conditioning AC processes and impact on governance outcomes, including fraud and irregularities. Likewise, while Bedard et al. (2004), Krishnan (2005) and Yang and Krishnan (2005) provide recent evidence of a statistical association between AC characteristics and earnings management, this paper reveals that the 
engagement of the $\mathrm{AC}$ in non-routine matters, outside of scheduled meetings, and the use of the $\mathrm{AC}$ as any ally, arbiter and/or a threat significantly conditions governance outcomes. In further theorizing $\mathrm{AC}$ effectiveness and in formulating public policy, due consideration needs to be given to the AC's ability to address the non-routine situations and to the danger that ACs may be used to enhance the appearance of effective governance while its role in organizational affairs is limited to formal and routine processes.

In conclusion, the case study evidence in this paper suggests that, in addition to formal processes, governance outcomes are significantly influenced by informal processes and power relationships surrounding the $\mathrm{AC}$ - dimensions that are largely unexplored in extant $\mathrm{AC}$ research. These dimensions interact with each other in producing governance outcomes and it is difficult to isolate the effect of one from another. Although in this paper empirical elaboration on these dimensions has been constrained to some extent by the access and confidentiality issues involved in conducting research with board members and senior management, the insights from the analysis complement existing research and may potentially be useful in developing theoretical ideas about ACs within their organizational and institutional context for future investigation.

\section{Notes}

1. In the USA, following the Sarbanes-Oxley Act 2002, the SEC (2003) has adopted rules which requires, for example, one financial expert member of the $\mathrm{AC}$ to be identified by name, and if there is no financial expert this needs to be disclosed and explained. In Australia, ACs have been advocated in response to high profile corporate failures (Guthrie and Turnbull, 1995) and, following the Ramsay Report's (2001) recommendations, the government has proposed legislation to make ACs mandatory for all publicly listed companies (Australian Treasury, 2002). In the UK, further guidance has been issued about role of the AC (Smith Committee, 2003) and the independence of non-executive directors (Higgs, 2003) in an attempt to strengthen governance.

2. The approach is consistent with the view that "traditional worries about the loss of control and generalisability, and the problems of theory driven data collection, can be traded off against the need for opportunism in an under-researched area, and the merits of richness and interest" (Power, 2003, p. 390). Also consistent with Laughlin's (1995) and Humphrey and Scapens' (1996) observations concerning prior level of theorization, the analytical framework is intended as a "skeletal" guide providing some broad understanding of relationships and not a definable theory for testing hypotheses. In applying a skeletal framework, this paper recognizes the broader potential of case studies to generate observations that can contribute to theory building and also endeavours to avoid the extremity of studies that seek merely to illustrate the application of a particular theory to a case.

3. Most quantitative studies, using publicly available data, often tend to exclude companies from the financial services and regulatory sector. There is however no particular reason to believe that the findings of this paper with respect to the role of informal processes and power relationships in conditioning governance outcomes are likely to have due to it company being in the financial services sector.

4. That is at the time initial contact was made with the organization and when data collection for the case begun.

\section{Audit committee effectiveness}

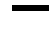




\section{AAAJ \\ 20,5}

\section{6}

6. In the UK, the term "building society" refers to institutions established historically as mutual rather than shareholder based organizations, primarily for the purposes of offering savings opportunities and loan finance, mainly through mortgages for home ownership.

6. Although an $\mathrm{AC}$ is not a legislative requirement, the Banking Act 1987 sch. 3, para. 3, requires authorised institutions to include an appropriate number of directors without executive responsibilities and the Bank of England, as sector supervisor, is required to have regard to their functions in determining the adequacy of internal controls (Collier, 1993).

7. For instance, when the external auditors were appointed, following a tender process, the AC contributed to the discussion but the appointment recommended to shareholders was decided by the Board Chair, Deputy Chair, two or three other members of the Board and the Chief Executive.

8. See, for example, the EC (2006) 8th Directive and the recommendations of the Smith Committee (2003) in the UK.

\section{References}

Abbott, L.J., Parker, S. and Peters, G.F. (2004), "Audit committee characteristics and restatements", Auditing: Journal of Practice \& Theory, Vol. 19 No. 2, pp. 47-66.

Australian Treasury (2002), Corporate Disclosure: Strengthening the Financial Reporting Framework, CLERP9, Department of Treasury, Commonwealth of Australia, Canberra, available at: www.treasury.gov.au

Beasley, M.S., Carcello, J.V., Hermanson, D.V. and Lapides, P.D. (2000), "Fraudulent financial reporting: consideration of industry traits and corporate governance mechanisms", Accounting Horizons, Vol. 14 No. 4, pp. 441-54.

Bedard, J., Chtourou, S.M. and Courteau, L. (2004), "The effect of audit committee expertise, independence and activity on aggressive earnings management", Auditing: A Journal of Practice \& Theory, Vol. 23 No. 2, pp. 13-35.

Blue Ribbon Committee (1999), Report and Recommendations of the Blue Ribbon Committee on Improving the Effectiveness of Audit Committees, NYSE and NASD, New York, NY.

Bradbury, M.E. (1990), "The incentives for voluntary audit committee formation", Journal of Accounting \& Public Policy, Vol. 9, pp. 19-36.

Burns, J.E. (2000), "The dynamics of accounting change: interplay between new practices, routines, institutions, power and politics", Accounting, Auditing \& Accountability Journal, Vol. 13 No. 5, pp. 566-96.

Business Week (2002), Business Week, 21 January, p. 28.

Cadbury Committee (1992), Financial Aspects of Corporate Governance, Gee Publishing Ltd, London.

Carcello, J.V. and Neal, T.L. (2003), "Audit committee characteristics and auditor dismissals following 'new' going-concern reports”, Accounting Review, Vol. 78 No. 1, pp. 95-118.

Clegg, S. (1989), Frameworks of Power, Sage, London.

Collier, P. (1993), "Factors affecting the formation of audit committees in major UK listed companies", Accounting \& Business Research, Vol. 23 No. 91A, pp. 421-30.

Collier, P. and Zaman, M. (2005), “Convergence in European corporate governance”, Corporate Governance: International Review, Vol. 13 No. 4, pp. 753-68.

DeZoort, F.T., Hermanson, D.R., Archambeault, D.S. and Reed, S.A. (2002), "Audit committee effectiveness: a synthesis of the empirical audit committee literature", Journal of Accounting Literature, Vol. 21, pp. 38-75. 
Dirsmith, M.W. and Covaleski, M.A. (1985), "Informal communications, nonformal communications and mentoring in public accounting firms", Accounting, Organizations and Society, Vol. 10 No. 2, pp. 149-69.

\section{Audit committee} effectiveness

EC (2006), 8th Directive on Statutory Audit of Annual Accounts and Consolidated Accounts, 2006/43/EC, European Commission, Brussels.

Gendron, Y., Bedard, J. and Gosselin, M. (2004), "Getting inside the black-box: a filed study of practices in 'effective' audit committees”, Auditing: A Journal of Practice \& Theory, Vol. 23 No. 1, pp. 153-71.

Guthrie, J. and Turnbull, S. (1995), "Audit committees: is there a role for corporate senates and/or shareholder councils?”, Corporate Governance: An International Review, Vol. 3 No. 2, pp. 78-9.

Hall, R.H. (1999), Organizations: Structures, Processes and Outcomes, Prentice-Hall, Englewood Cliffs, NJ.

Hampel Committee (1998), Committee on Corporate Governance: Final Report, Gee Publishing Ltd, London.

Hardy, C. (1996), "Understanding power: bringing about strategic change", British Journal of Management, Vol. 7, pp. S3-S16.

Higgs, D. (2003), Review of the Role and Effectiveness of Non-executive Directors, Department of Trade and Industry, London.

Hooks, L., Kaplan, S.E. and Schultz, J. (1994), "Enhancing communication to assist fraud prevention and detection", Auditing: A Journal of Practice \& Theory, Vol. 13 No. 2, pp. 86-116.

Humphrey, C. and Scapens, R.W. (1996), "Theories and case studies of organizational accounting practices: limitation or liberation?", Accounting, Auditing \& Accountability Journal, Vol. 9 No. 4, pp. 86-106.

Klein, A. (2002), "Economic determinants of audit committee independence", Accounting Review, Vol. 77, pp. 435-52.

Krishnan, J. (2005), "Audit committee quality and internal control: an empirical analysis", Accounting Review, Vol. 80 No. 2, pp. 649-75.

Laughlin, R. (1995), "Empirical research in accounting: alternative approaches and a case for 'middle-range' thinking”, Accounting, Auditing \& Accountability Journal, Vol. 8 No. 1, pp. 63-87.

McMullen, D.A. (1996), "Audit committee performance: an investigation of the consequences associated with audit committees”, Auditing: Journal of Practice \& Theory, Vol. 15 No. 1, pp. 87-103.

Menon, K. and Williams, J.D. (1994), "The use of audit committees for monitoring", Journal of Accounting \& Public Policy, Vol. 13, pp. 121-39.

Miceli, M.P. and Near, J. (1984), “The relationships among beliefs, organizational position, and whistleblowing status: a discriminant analysis", Academy of Management Journal, Vol. 27 No. 4, pp. 687-705.

Pettigrew, A. (1992), "On studying managerial elites", Strategic Management Journal, Vol. 13, pp. $163-82$.

Pfeffer, J. (1992), Managing with Power, Harvard Business School Press, Boston, MA.

Pincus, K., Rusbarsky, M. and Wong, J. (1989), "Voluntary formation of corporate audit committees among NASDAQ firms", Journal of Accounting \& Public Policy, Vol. 8, pp. 239-65. 


\section{AAAJ \\ 20,5}

788
Power, M. (2003), "Auditing and the production of legitimacy", Accounting, Organizations and Society, Vol. 28, pp. 379-94.

Ramsay Report (2001), Independence of Australian Company Auditors: Review of Current Australian Requirements and Proposals for Reform, Department of Treasury, Commonwealth of Australia, Canberra, available at: available at: www.treasury.gov.au

Sarens, G. and De Beelde, I. (2006), "Internal audit: the expert in providing comfort to the audit committee", working paper, University of Ghent, Belgium.

Scott, W.R. (2001), Institutions and Organizations, 2nd ed., Sage, Thousand Oaks, CA.

SEC (2003), Final Rule: Disclosure Required by Section 406 and 407 of the Sarbanes-Oxley Act of 2002, Release Nos. 33-8177; 34-47235, available at: www.sec.gov/rules/final/33-8177.htm

Shapira, Z. (2000), "Governance in organizations: a cognitive perspective", Journal of Management and Governance, Vol. 4, pp. 53-67.

Smith Committee (2003), Audit Committee Combined Code Guidance, Financial Reporting Council, London.

Spira, L. (2002), The Audit Committee: Performing Corporate Governance, Kluwer Academic Publishers, London.

Turley, S. and Zaman, M. (2003), Public Policy on Corporate Audit Committees, ACCA Research Paper, available at: www.accaglobal.com/pubs/publicinterest/activities/research/ research_archive/orp_035_001.pdf

Turley, S. and Zaman, M. (2004), “Corporate governance effects of audit committees”, Journal of Management \& Governance, Vol. 8, pp. 305-32.

Yang, J.S. and Krishnan, J. (2005), “Audit committees and quarterly earnings”, International Journal of Auditing, Vol. 9 No. 3, pp. 201-20.

\section{Corresponding author:}

Mahbub Zaman can be contacted at: mahbub.zaman@mbs.ac.uk

To purchase reprints of this article please e-mail: reprints@emeraldinsight.com Or visit our web site for further details: www.emeraldinsight.com/reprints 